\title{
EKSISTENSI MAJELIS TAKLIM DALAM MEMBUMIKAN HADIS MELALUI ZIKIR
}

\author{
Oleh. Junaid bin Junaid \\ Institut Agama Islam Negeri (IAIN) Bone. \\ Email: junaidede@yahoo.co.id
}

\begin{abstract}
Socializing the Prophet's hadith through zikr includes the mu'tabar hadith and the Prophet's tradition which deal directly with the problem of zikr, the majority of which are used as a foundation in the taklim assembly, so it is clear that in Islam zikr has relevance that can create peace of mind for every Muslim in carrying out activities in daily life -day. In this case directly related to hablun min Allah and hablun min annas.

Through Majelis Taklim as a forum for religious formation and personality which functions as a stabilizer in all movements of Muslim life activities, the hadith as the second source of law in Islam is very appropriate if the Islamic nuances receive attention and support from the community, so that the community has a balance of intellectual and mental-spiritual potential in an effort to deal with changing times from an increasingly global and advanced era.
\end{abstract}

Keywords: Hadith; Majlis Taklim; Zikr.

\begin{abstract}
Abstrak
Membumikan hadits Nabi melalui zikir meliputi hadits mu'tabar dan tradisi Nabi Saw. yang berhubungan langsung dengan masalah zikir, mayoritas digunakan sebagai landasan dalam majelis taklim, sehingga jelas bahwa dalam Islam, zikir memiliki relevansi yang dapat menciptakan ketenangan batin bagi setiap muslim dalam melakukan aktivitas pada kehidupan sehari-hari. Dalam hal ini berkaitan langsung dengan hablun min Allah dan hablun min annas.

Melalui Majelis Taklim sebagai forum untuk pembentukan jiwa dan kepribadian religius yang berfungsi sebagai stabilisator dalam semua pergerakan aktivitas kehidupan umat Islam, maka hadis sebagai sumber hukum kedua dalam Islam, sangat tepat jika kegiatan yang bernuansa Islami ini mendapat perhatian dan dukungan dari masyarakat, sehingga masyarakat memiliki keseimbangan potensi spiritual intelektual dan mental dalam upaya menghadapi perubahan zaman dari era yang semakin global dan maju.
\end{abstract}

Kata Kunci: Hadis; Majlis Taklim; Zikir. 


\section{A. Pendahuluan}

Islam merupakan risalah terakhir dari langit ke bumi yang universal. Islam pulalah yang telah membawa dunia menuju revolusi besar dalam berbagai aspek kehidupan. Islam tidak hanya mengatur hubungan antara manusia dengan pencipta-Nya, tetapi juga mengatur hubungan antara manusia dengan manusia, dan sebagainya. ${ }^{1}$

Aturan itu diramu dengan sangat sempurna sehingga umat yang patuh pada aturan-aturan yang dibuat, akan menemukan suatu bentuk kebahagiaan dan kedamaian dalam mengarungi kehidupan tersebut, utamanya dunia dan juga kemaslahatan di akhirat. Salah satu sumber aturan tersebut adalah berasal dari hadis Nabi Saw.

Hadis merupakan segala perkataan (sabda), perbuatan, ketetapan dan persetujuan dari Nabi Muhammad Saw. yang dijadikan ketetapan ataupun hukum dalam agama Islam. Kedudukan hadis merupakan sumber hukum kedua setelah al-Qur'an. ${ }^{2}$ Siapa yang mengikuti petunjuk-petunjuk hadis pasti akan sehat jasmani, rohani dan sosialnya. Hal ini telah dibuktikan oleh umat Islam sejak zaman nabi Saw. sampai zaman keemasannya.

Dengan perkembangan sumber daya manusia, yakni kualitas iman dan taqwa yang kuat dan didukung oleh perkembangan teknologi, maka umat Islam pada masa itu menguasai dunia. Umat Islam baru dapat dikalahkan oleh orang kafir setelah meninggalkan ajaran Islam. ${ }^{3}$ Dan untuk mengembalikan kembali kejayaan tersebut, salah satunya adalah dengan memperbaiki aspek kejiwaan umat Islam melalui jalan zikir kepada Allah Swt.

Tampak sekali, bahwa zikir merupakan salah satu ibadah yang paling utama dan merupakan amal ibadah yang paling dapat mendekatkan diri kita Allah Swt. Oleh karena itu, di dalam hadis nabi Saw. banyak ditemukan tentang hadis yang memerintahkan kepada umat manusia untuk melakukan zikir disertai dengan

${ }^{1}$ Zaithunah Subari, Membina Keluarga Sakinah (Cet. I; Yogyakarta: Pustaka Amani, 2004), h. 47.

${ }^{2}$ Endang Soetari, Ilmu Hadis Kajian Riwayah, (Bandung: Mimbar Pustaka, 2008), h. 10.

${ }^{3}$ R.H. Su'dan, Al-Qur'an dan Panduan Kesehatan Masyarakat, (Yogyakarta: Dana Bhakti Prima Jasa, 1997), h. 285. 
pujian dan sanjungan kepada Allah Swt. kepada mereka yang melaksanakannya dan salah satu sumbernya adalah hadis nabi Saw..

Dalam kehidupan sehari-hari, berzikir sangat penting untuk diterapkan khususnya bagi umat muslim, karena zikir tersebut merupakan hubungan antara seorang hamba dengan Allah Swt.. Namun dalam prakteknya zikir jarang sekali diamalkan, walau mungkin ada itu pun hanya sebagian manusia yang selalu mengamalkannya. Kebanyakan orang berzikir pada waktu dan keadaan tertentu. Terkadang manusia berzikir dan mengingat Allah Swt.. hanya saat dalam kesusahan dan tertimpa masalah saja.

Dalam hubungannya sebagai sebuah kegiatan membumikan hadis nabi Saw., maka zikir dapat dimaknai sebagai satu fungsi intelektual, ingatan kita akan apa yang telah dipelajari, informasi dan pengalaman sebelumnya, memungkinkan kita untuk memecahkan problem-problem baru yang kita hadapi, juga sangat membantu kita dalam melangkah maju untuk memperoleh informasi dan menerima realitas baru. Namun pengertian yang dimaksud adalah zikir kepada Allah atau mengingat Allah. ${ }^{4}$ Dan Zikir itu tidak sekadar ajaran agama akan tetapi salah satu solusi yang efektif dalam menanggulangi permasalahan yang menghimpit batin seseorang, orang bisa melakukan transendensi kepada Allah dengan media zikir, untuk menyerahkan semua urusan kehidupannya, permasalahan batin bisa berdampak pada permasalahan fisik, sehingga zikir adalah salah satu ibadah yang mampu membawa dampak positif terhadap kesehatan mental. $^{5}$

Tampak sekali, bahwa Zikrullah juga sangat berpengaruh sekali terhadap prilaku seseorang ,karena dengan banyak berzikir orang tersebut secara otomatis ingat akan perintah Allah dan menjahui larangan Allah, sehingga prilaku dan tindak tanduknya lebih santun kepada siapa saja. Karena dengan melakukan aktifitas ritual zikir pada setiap tindakan, maka dengan sendirinya terdapat satu

${ }^{4}$ M. Muhsin Jamil. Tarekat dan Dinamika Sosial dan Politik Tafsir Sosial Sufi, (Yogyakarta: Pustaka Pelajar, 2005), h. 69.

${ }^{5}$ Ahmad Mujib el Sirozi, Fakta Keajaiban Dibalik Perintah dan Larangan Allah, (Jakarta: Listafariska Putra, 2009), h. 60. 
kontrol yang baik dari dalam jiwa setiap jamaah majelis taklim. Dan ini merupakan satu bentuk perubahan dari jamaah majelis takllim setelah memahami kandungan makna dari hadis-hadis nabi Saw. dalam sebuah ritual zikir.

\section{B. Pembahasan}

\section{Terminologi Majelis Taklim}

Secara etimologi, kata majelis taklim berasal dari dua suku kata, yaitu kata majelis dan kata taklim. Dalam bahasa Arab kata majlis adalah bentuk isim makan ( kata tempat) kata kerja yang artinya " tempat duduk, tempat sidang, dewan. ${ }^{6}$ Sedangkan kata taklim dalam bahasa Arab merupakan masdar dari kata kerja yang mempunyai arti " pengajaran",

Demikian pula, dalam kamus bahasa Indonesia disebutkan, bahwa pengertian dari kata majelis adalah lembaga organisasi sebagai wadah pengajian dan kata Majelis dalam kalangan ulama' adalah lembaga masyarakat non pemerintah yang terdiri atas para ulama' Islam. $^{8}$ Sedang, arti Taklim adalah Pengajaran.

Adapun pengertian majelis taklim secara terminology di antaranya adalah sebagai berikut :

a. Majelis taklim adalah wadah pembentuk jiwa dan kepribadian yang agamis yang berfungsi sebagai stabilisator dalam seluruh gerak aktivitas kehidupan umat Islam Indonesia, maka sudah selayaknya kegiatan-kegiatan yang bernuansa Islami mendapat perhatian dan dukungan dari masyarakat, sehingga tercipta insan-insan yang memiliki keseimbangan antara potensi intelektual dan mental spiritual dalam upaya menghadapi perubahan zaman yang semakin global dan maju.

b. Majelis takim adalah lembaga pendidikan non-formal Islam yang memiliki kurikulum sendiri/aturan sendiri, yang diselenggarakan secara berkala dan

${ }^{6}$ Ahmad Warson Munawir, Al-Munawir Kamus Bahasa Indonesia, (Yogyakarta: Pustaka Progresif, 1997), cet. Ke- 14, h. 202

${ }^{7}$ Ahmad Warson Munawir, Al-Munawir Kamus Bahasa Indonesia, h. 1038.

${ }^{8}$ Departemen Pendidikan dan Kebudayaan, Kamus Besar Bahasa Indonesia Pusat Bahasa, (Jakarta: PT.Gramedia Pustaka Utama, 2008), cet. Ke-4, hal. 859. 
teratur, dan diikuti oleh jama'ah yang relatif banyak dan bertujuan untuk membina dan mengembangkan hubungan yang santun dan serasi antara manusia dan Allah, manusia dan sesamanya dan manusia dan lingkungannya, dalam rangka membina masyarakat yang bertaqwa kepada Allah Swt.

c. Majelis taklim adalah salah satu lembaga pendidikan non-formal yang bertujuan meningkatkan keimanan dan ketakwaan kepada Allah Swt. dan akhlak mulia bagi jamaáhnya, serta mewujudkan rahmat bagi alam semesta. Dalam prakteknya, majelis taklim merupakan tempat pangajaran atau pendidikan agama islam yang paling fleksibel dan tidak terikat oleh waktu. ${ }^{9}$

Dengan demikian majelis taklim menjadi lembaga pendidikan keagamaan alternatif bagi mereka yang tidak memiliki cukup tenaga, waktu, dan kesempatan menimba ilmu agama dijalur pendidikan formal. Inilah yang menjadikan majelis taklim memiliki nilai karkteristik tersendiri dibanding lembaga-lembaga pendidikan non formal lainnya.

Berbagai kegiatan majelis taklim yang telah dilakukan merupakan proses pendidikan yang mengarah kepada internalisasi nilai-nilai agama sehingga perempuan mampu mereflesikan tatanan normatif yang mereka pelajari dalam realitas kehidupan sehari-hari. Majelis taklim adalah wadah pembentukan jiwa dan kepribadian yang agamis yang berfungsi sebagai stabilisator dalam seluruh gerak aktivitas kehidupan umat Islam, maka sudah selayaknya kegiatan-kegiatan yang bernuansa islami mendapat perhatian dan dukungan dari masyarakat, sehingga tercipta insan-insan yang memiliki keseimbangan antara potensi intelektual dan mental spiritual dalam upaya menghadapi perubahan zaman yang semakin global dan maju.

Pada sisi lain, majelis taklim dapat juga berperan penting dalam pembentukan karakter anak dengan memberikan pendidikan yang baik untuk perempuan itu berarti memberi peluang besar menjadikan generasi penerus bangsa yang kuat secara fisik dan amanah secara psikis. Majelis taklim

\footnotetext{
${ }^{9}$ Ahmad Subari, Peran Majelis Taklim Dalam Pengembangan Ajaran KeIslaman (Cet. 1; Solo: Ramadhani, 2000), h. 52.
} 
merupakan salah satu wadah yang anggotanya mayoritas perempuan mencari ilmu, mengembangkan daya kreatif bakat seni, yang ada pada dirinya, bersilaturahmi, dan berzikir bersama.

Adapun upaya memaksimalkan peran dan fungsi majelis taklim yang perlu dilakukan adalah:

a. Memperkuat fungsi majelis taklim sebagai tempat pengajaran agama Islam secara luas, yang meliputi pengkajian tentang pokok-pokok ajaran Islam dan kaitannya dengan persoalan sehari-hari yang dihadapi oleh umat Islam itu sendiri. Pengetahuan pokok ajaran Islam seperti aqidah, syariah', akhlak, tafsir, hadis dan tarikh sudah semestinya diintegrasikan dengan sisi kehidupan nyata yang selalu muncul dalam keseharian umat. Hal ini diniscayakan sesuai dengan sumber pokok ajaran Islam, yaitu al-Qur'an dan al-Sunnah yang menyajikan banyak hal yang bisa dipelajari oleh setiap muslim dalam mengikuti suri teladan yang dicontohkan oleh Nabi Muhammad Saw. sebagai pembawa syariat Islam. Kaitan Islam dengan ilmu-ilmu terapan yang berhubungan langsung dengan nafas kehidupan manusia dirumuskan dalam beberapa pokok bahasan menyangkut hubungan Islam dengan lingkungan, kesehatan, kesenian, politik dan psikologi. Selain mengajarkan tentang ibadah transendental dalam arti hubungan vertikal antara manusia dengan Allah Swt, tapi juga mencakup bagaimana seharusnya seorang muslim menjalin hubungan horizontal dengan sesama manusia dan lingkungannya.

b. Meningkatkan fungsi majelis taklim dari tempat penyelenggaraan pengajian menjadi wahana melakukan kaderisasi umat Islam. Kaderisasi adalah suatu sistem menyiapkan generasi yang akan datang. Sistem ini dikemas dan diakltualisasikan dengan sungguh di majelis taklim. Setiap majelis taklim, sesuai dengan tujuan, misi dan visinya harus melakukan pengkaderan di kalangan jamaáhnya. Dengan demikian keberlangsungan majelis taklim akan terus berlanjut.

c. Mengembangkan fungsi konseling. Sebagai salah satu lembaga pendidikan non-formal, majelis taklim bertanggung jawab untuk mendidik dan 
membantu jamaáhnya untuk dapat beradaptasi dengan lingkungan masyarakatnya dan mampu memecahkan berbagai persoalan hidup yang dihadapinya. Melalui kegiatan ta'lim muta'alim (belajar-mengajar) yang dikemas sedemikian rupa diharapkan dapat membantu jamaáh yang mengalami persoalan-persoalan kehidupan, baik pribadi maupun sosial. Dalam situasi seperti inilah peran dan fungsi konseling akan terasa diperlukan oleh berbagai pihak yang terlibat di majelis taklim, terutama para jamaáhnya.

d. Menjadikan majelis taklim sebagai pusat pengembangan keterampilan atau skill jamaáh. Setiap muslim idealnya bisa berperan ganda dalam kehidupannya, yaitu sebagai 'abid (penyembah Allah) dan sekaligus sebagai khalifah fi al-ardh (orang yang memakmurkan bumi). Sebagai penyembah Allah Swt, seorang muslim mesti ikhlas menjadikan hidupnya sebagai media pengabdian diri kepada-Nya. Dan sebagai pemakmur di muka bumi, setiap muslim harus berperan dalam mencegah dan memperbaiki kerusakan-kerusakan yang terjadi disekelilingnya. Dalam konteks inilah majelis taklim bisa menjadi pusat pengembangan keterampilan/skill bagi jamaáhnya. Keterampilan yang dimaksud sesuai dengan aneka ragam bakat yang dimiliki oleh setiap individu dalam majelis taklim tersebut. Keterampilan yang dapat dikembangkan meliputi: keterampilan dasar (basic skills) yakni membaca, menulis, berbicara dan lain sebagainya; keterampilan hidup sehari-hari (daily living skills) yang berfungsi untuk melakukan aktifitas untuk memenuhi kebutuhan sehari-harinya; keterampilan personal/ sosial (personal/social skills); keterampilan mental (mental skills); keterampilan pekerjaan (occupational skills); dan keterampilan atau kecerdasan spiritual (spiritual quotient, $S Q$ ).

e. Meningkatkan peran pemberdayaan masyarakat melalui pengembangan potensi ekonomi dan sosial. Sebagai tempat berkumpulnya jamaáh, majelis taklim diharapkan bisa menjadi media sosial dalam mengkomunikasikan upaya-upaya pembangunan umat, baik secara lahir maupun batin. Melalui majelis taklim yang merupakan sarana efektif dalam interaksi sosial dapat 
disampaikan informasi yang dapat menggugah jamaáhnya untuk berfikir dan melakukan langkah-langkah produktif dalam rangka pemberdayaan ekonomi dan sosial jamaáh. Pemberdayaan ekonomi dapat berwujud dukungan dana, baik yang bersifat mandiri maupun menjalin kerjasama dengan donator, baik pemerintah maupun swasta.

f. Menjadikan majelis taklim sebagai wadah silaturrahmi dan rekreasi ruhani. Majelis taklim tidak hanya berfungsi sebagai tempat belajar agama Islam, namun juga mampu member warna bagi jamaáhnya dalam pembinaan solidaritas sosial yang kuat antar umat Islam melalui silaturrahim. Selain itu juga, majelis taklim bisa memberikan ruang yang cukup lapang dalam menjalankan fungsi rekreasi ruhani melalui nasehat-nasehat dan pesanpesan moral yang diajarkannya. Dalam situasi dan kondisi itulah, melalui majelis taklim akan tertanam harmoni sosial yang dapat dipetik oleh semua jamaáh yang kemudian mengkondisikan suatu jalinan kebersamaan sebagai hamba-hamba Allah yang sama-sama mempunyai hajat mengisi ruang hati dengan siraman-siraman dakwah Islamiyah.

g. Mengembangkan fungsi sebagai pusat komunikasi dan informasi. Melalui pengembangan fungsi ini diharapkan jamaáh akan selalu mendapatkan informasi yang up to date mengenai perkembangan sosial budaya yang terjadi disekitarnya maupun perkembangan dunia yang terjadi dengan sangat cepat. Sebagai pusat informasi, majelis taklim melalui pengurusnya mampu mengumpulkan, menyimpan, memproses dan menyaring berita, data, opini dan komentar secara jelas serta memberikan petunjuk dan arahan bagaimana seharusnya jamaáh menyikapi semua hal-hal yang terjadi.

h. Mengembangkan peran sebagai tempat berkembangnya budaya Islam. Sebagai institusi pendidikan nonformal majelis taklim dapat menciptakan budayanya sendiri, misalnya budaya dalam berpakaian dan perhiasan yang tentunya mencerminkan bagaimana seharusnya jamaáh atau masyarakat yang terlibat didalamnya untuk selalu membiasakan tata cara berpakaian yang sesuai dengan ajaran Islam. Begitu pula dalam hal budaya makanan, minuman dan kebiasaan-kebiasaan lainnya. 
i. Menjadikan majelis taklim sebagai lembaga kontrol sosial (social control). Dengan fungsi control ini. Eksistensi majelis taklim akan semakin diperlukan di tengah-tengah masyarakat. Majelis taklim berperan besar dalam transfer pengetahuan dari pengajar (mualim) kepada jamaáhnya dan sekaligus berperan besar dalam memecahkan problematika sosial keagamaan yang dihadapi umat. Seperti misalnya dalam hal mengantisipasi aliran-aliran sesat, pendangkalan akidah, kemaksiatan dan prilaku asosial lainnya yang selalu muncul dan mengancam sendi-sendi kehidupan umat manusia, khususnya umat Islam. Disinilah majelis taklim akan tampil efektif sebagai agen kontrol sosial melalui berbagai peranan dan fungsi yang dijalankannya. ${ }^{10}$

Dengan demikian, bahwasanya tidak bisa dipungkiri bahwa keberadaan majelis taklim dalam gerak dinamika sosial masyarakat muslim akan tetap ada sejalan dengan perkembangan dakwah Islam. Untuk itu, guna dapat meningkatkan perannya dalam memberdayakan para jama'ah yang umumnya merupakan umat Islam dalam beragam kelas sosial dan tingkat penghidupannya, majelis taklim dituntut untuk terus dapat meningkatkan kualitas dirinya agar dapat berperan lebih besar dalam menjembatani kesenjangan yang terjadi antara kondisi nyata umat Islam dengan perkembangan dunia yang semakin maju. Di sini, majelis taklim dituntut untuk menjadi agen perubahan (agent of change), membawa umat Islam menuju kondisi yang lebih maju sesuai dengan tujuan da'wah yaitu untuk mencapai masyarakat khairu ummah.

\section{Majelis Taklim dan Hadis Nabi Saw. Tentang Zikir}

Hukum Islam merupakan sistem hukum yang universal karena memuat berbagai persoalan kehidupan manusia. Universalitas hukum Islam dapat dilihat dari sistem hukumnya yang mencakup semua aspek perbuatan mukallaf. Di samping itu, universalitas hukum Islam juga dapat dilihat dari sumbernya yang diyakini mempunyai kebenaran yang absolut dan mempunyai daya adaptability terhadap perubahan zaman, keadaan dan adat.

\footnotetext{
${ }^{10}$ Ahmad Subari, Peran Majelis Taklim Dalam Pengembangan Ajaran KeIslaman, h. 59.
} 
Segala aspek yang menyangkut kehidupan manusia secara umum terbagi menjadi dua kelompok. Pertama, aspek yang menyangkut hubungan lahir manusia dengan Allah (hablun min Allah), yang dalam bahasa agama sering disebut dengan al-ibadat. Aspek tersebut bertujuan untuk menjaga hubungan harmonis antara manusia dengan Sang Pencipta, Allah Swt. Kedua, aspek yang berkaitan dengan hubungan manusia dengan manusia (hablun min al-Nas) atau tertuang dalam hukum muamalat. Aspek tersebut bertujuan untuk menjaga hubungan antara manusia dengan manusia lainnya dengan cara yang tertib dan dapat menghindarkan mereka dari kehinaan, kemiskinan serta ancaman Allah Swt. Aspek- aspek tersebut akan selalu berhubungan dengan kehidupan manusia, baik yang bersifat pribadi maupun sosial.

Keberadaan manusia sebagai pribadi mempunyai ruang yang terbatas pada penentuan hak dan kewajiban individu. Sedangkan keberadaan manusia sebagai bagian dari sosial memiliki ruang yang lebih luas dan terbuka, dengan berdasarkan pada norma, etika, dan nilai-nilai sosial yang berkembang dalam masyarakat. ${ }^{11}$ Salah satu hal urgen dalam kehidupan sehari-hari adalah yang berhubugan dengan kejiwaan melalui zikir.

Sebagai sumber ajaran Islam yang kedua setelah al-Qur'an dan juga sebagai bayan terhadap ayat-ayat al-Qur'an yang masih bersifat global. Sehingga urgen sekali untuk selalu dan senantiasa hadis nabi Saw. tersebut menjadi sebuah referensi dalam memahami isi ajaran Islam dengan berdasar pada pemikiran yang objektif.

Berdasarkan pada realitas yang terjadi pada majelis taklim, khususnya dalam hal pengaplikasian dan pengamalan hadis-hadis nabi Saw. yang berhubungan langsung dengan materi zikir, ada beberapa sumber hadis nabi Saw. yang dijadikan landasan dan melakukan satu bentuk kegiatan zikir. Diantaranya adalah sebagai berikut:

\footnotetext{
${ }^{11}$ Khoiruddin Nasution, Hukum Perkawinan \& Warisan di Dunia Muslim Modern (Cet. I; Yogyakarta: ACAdeMIA, 2012), h. 219-220.
} 


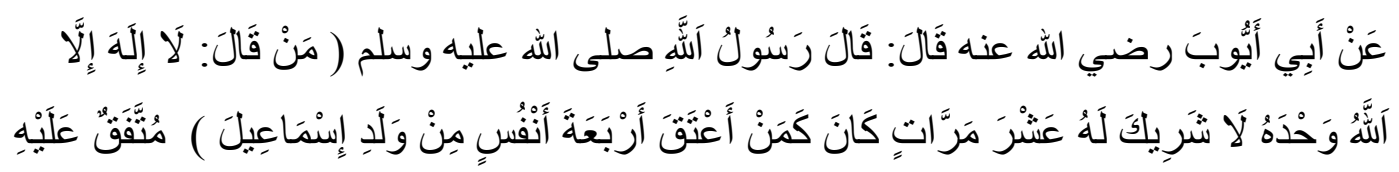

Artinya: "Dari Abu Ayyub al-Anshory Radliyallaahu 'anhu bahwa Rasulullah Shallallaahu 'alaihi wa Sallam bersabda: "Barangsiapa membaca Tidak ada Tuhan selain Allah yang maha esa tiada sekutu bagi-Nya segala kerajaan dan puji hanya milik-Nya dan Dia Maha Kuasa atas segala sesuatu sepuluh kali ia seperti orang yang memerdekakan empat belas orang dari anak Ismail.” (HR.Muttafaq Alaihi).

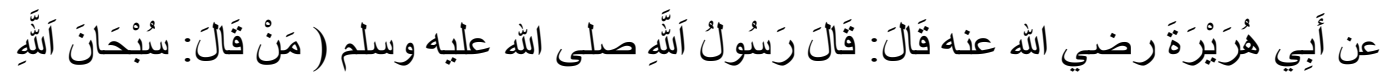

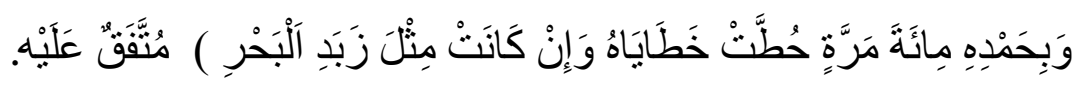

Artinya:"Dari Abu Hurairah Radliyallaahu 'anhu bahwa Rasulullah Shallallaahu 'alaihi wa Sallam bersabda: "Barangsiapa membaca Maha suci Allah dan aku memuji-Nya seratus kali, dihapuslah segala dosanya walaupun laksana buih air laut." (HR. Muttafaq Alaihi).

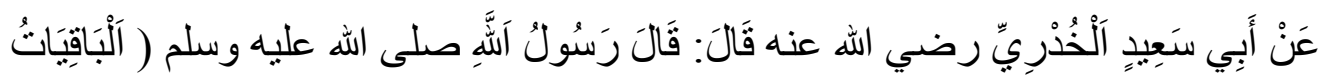

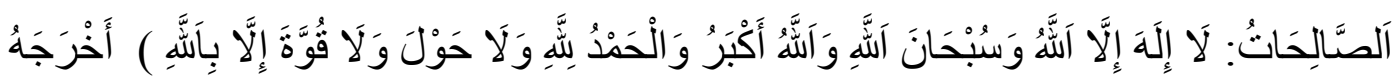

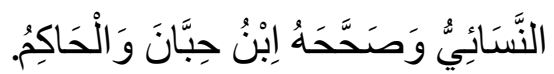

Artinya: "Dari Abu Said al-Khudry Radliyallaahu 'anhu bahwa Rasulullah Shallallaahu 'alaihi wa Sallam bersabda: "Bacaan yang kekal dan baik ialah; Tidak ada Tuhan selain Allah Mahasuci Allah Allah Maha besar segala puji milik Allah tidak ada daya dan kekuatan kecuali dengan kehendak Allah." (HR. Al-Nasa'i).

Tampak sekali, hadis-hadis di atas adalah bersumber dari kitab-kitab hadis yang mu'tabar, yaitu berdasar atau merujuk pada al-kutubu tis 'ah. Dan kitab-kitab hadis inilah yang senantiasa masih eksis pada kekinian. Utamanya dalam dunia akademisi. Juga memiliki kualitas sebagai hadis sahih dan hasan. Karena berasal dari periwayat dan sanad-sanad yang sudah masyhur dan diakui keadilannya.

Disamping itu pula, bahwa hadis-hadis nabi Saw. tersebut berkaitan langsung dengan masalah zikir yang mayoritas dijadikan sebagai landasan oleh majelis taklim dalam membumikan hadis nabi Saw. melalui sebuah zikir, sehingga jelas sekali bahwa dalam syariat Islam zikir memiliki sebuah relevansi di dalamnya yang dapat menciptakan adanya satu ketenangan batin bagi setiap umat 
Islam dalam melaksanakan sebuah aktivitas pada khidupan sehari. Dalam hal ini yang berbungan langsung dengan hablun min Allah dan hablun min annas.

\section{Penutup}

Majelis Taklim adalah wadah pembentukan jiwa dan kepribadian yang agamis yang berfungsi sebagai stabilisator dalam seluruh gerak aktivitas kehidupan umat Islam, maka sudah selayaknya kegiatan-kegiatan yang bernuansa Islami mendapat perhatian dan dukungan dari masyarakat, sehingga tercipta insan-insan yang memiliki keseimbangan antara potensi intelektual dan mental spiritual dalam upaya menghadapi perubahan zaman yang semakin global dan maju.

Majelis taklim dalam membumikan hadis Nabi Saw. melalui zikir adalah berasal dari hadis yang mu'tabar, dan hadis-hadis nabi Saw. tersebut berkaitan langsung dengan masalah zikir yang mayoritas dijadikan sebagai landasan oleh majelis taklim dalam membumikan hadis Nabi Saw. melalui sebuah zikir, sehingga jelas sekali bahwa dalam syariat Islam zikir memiliki sebuah relevansi di dalamnya yang dapat menciptakan adanya satu ketenangan batin bagi setiap umat Islam dalam melaksanakan sebuah aktivitas pada khidupan sehari. Dalam hal ini yang berbungan langsung dengan hablun min Allah dan hablun min annas. 


\section{DAFTAR PUSTAKA}

Departemen Pendidikan dan Kebudayaan, Kamus Besar Bahasa Indonesia Pusat Bahasa, Jakarta: PT.Gramedia Pustaka Utama, 2008.

El Sirozi, Ahmad Mujib. Fakta Keajaiban Dibalik Perintah dan Larangan Allah, Jakarta: Listafariska Putra, 2009.

Jamil, M. Muhsin. Tarekat dan Dinamika Sosial dan Politik Tafsir Sosial Sufi, Yogyakarta: Pustaka Pelajar, 2005.

Munawir, Ahmad Warson. Al-Munawir Kamus Bahasa Indonesia, Yogyakarta: Pustaka Progresif, 1997.

Nasution, Khoiruddin. Hukum Perkawinan \& Warisan di Dunia Muslim Modern. Cet. I; Yogyakarta: ACAdeMIA, 2012.

Subari, Ahmad. Peran Majelis Taklim Dalam Pengembangan Ajaran KeIslaman. Cet. 1; Solo: Ramadhani, 2000.

Subari, Zaithunah. Membina Keluarga Sakinah . Cet. I; Yogyakarta: Pustaka Amani, 2004.

Soetari, Endang. Ilmu Hadis Kajian Riwayah. Bandung: Mimbar Pustaka, 2008.

Su'dan, R.H. Al-Qur'an dan Panduan Kesehatan Masyarakat, Yogyakarta: Dana Bhakti Prima Jasa, 1997. 